\title{
STILL LOOKING FOR AUDIENCE COSTS
}

\author{
Erik Gartzke and Yonatan Lupu
}

Eighteen years after publication of James Fearon's article stressing the importance of domestic audience costs in international crisis bargaining, we continue to look for clear evidence to support or falsify his argument. ${ }^{1}$ Notwithstanding the absence of a compelling empirical case for or against audience costs, much of the discipline has grown fond of Fearon's basic framework. A key reason for the importance of Fearon's claims has been the volume of theories that build on the hypothesis that leaders subject to popular rule are better able to generate audience costs. Scholars have relied on this logic, for example, to argue that democracies are more likely to win the wars they fight, ${ }^{2}$ that democracies are more reliable allies, ${ }^{3}$ and as an explanation for the democratic peace. $^{4}$

A pair of recent studies, motivated largely by limitations in the research designs of previous projects, offers evidence the authors interpret as contradicting audience cost theory. ${ }^{5}$ Although we share the authors' ambivalence about audience costs, we are not convinced by their evidence. What one seeks in looking for audience costs is evidence of a causal mechanism, not just of a causal effect. Historical case studies can be better suited to detecting causal mechanisms

Erik Gartzke is an associate professor in the Department of Political Science, University of California, San Diego.Yonatan Lupu is a Postdoctoral Research Associate at Princeton University. The authors contributed equally to this article, and their names are listed alphabetically.

${ }^{1}$ James D. Fearon, "Domestic Political Audiences and the Escalation of International Disputes," American Political Science Review 88, no. 3 (September 1994): 577-92.

${ }^{2}$ Dan Reiter and Allan C. Stam III, "Democracy, War Initiation, and Victory," American Political Science Review 92, no. 2 (June 1998): 377-89.

${ }^{3}$ Charles Lipson, Reliable Partners: How Democracies Have Made a Separate Peace (Princeton, NJ: Princeton University Press, 2003).

${ }^{4}$ Bruce Bueno de Mesquita, James D. Morrow, Randolph M. Siverson, and Alastair Smith, "An Institutional Explanation for the Democratic Peace," American Political Science Review 93, no. 4 (December 1999): 791-807.

5 Jack Snyder and Erica Borghard, "The Cost of Empty Threats: A Penny, Not a Pound," American Political Science Review 105, no. 3 (August 2011): 437-56; Marc Trachtenberg, "Audience Costs: An Historical Analysis," Security Studies (2012). 
than quantitative methods, and these two studies claim to be examining causal mechanisms. Yet process tracing is much less effective in assessing audience costs than Trachtenberg and others believe. After outlining relevant problems, we encourage scholars to theorize about and test more carefully key micro-foundations of audience cost theory.

\section{$\leq$ A $>$ AUDIENCE COSTS: A MECHANISM, NOT AN EFFECT $\leq \underline{A}>$}

Audience cost theory is best understood — and tested — as a theory about a causal mechanism. It is an argument about how $\mathrm{X}$ affects $\mathrm{Y}$, rather than an argument about whether $\mathrm{X}$ affects $\mathrm{Y} .{ }^{6}$ This makes the theory a particularly difficult one to test using standard research methods, quantitative and qualitative. ${ }^{7}$

Several researchers have attempted to test Fearon's theory using time-series crosssectional statistical analyses of crisis behavior. This literature has demonstrated, for example, that democratic dyads engage in less intra-crisis activity, ${ }^{8}$ leaders of democracies are less likely to back down, ${ }^{9}$ signals of resolve improve the probability of a challenger prevailing in a crisis between democracies, ${ }^{10}$ and democracies are less likely to face resistance when they initiate disputes. $^{11}$

Despite this evidence, quantitative tests of audience cost theory face at least four challenges. The first is potential endogeneity. Although research might establish, for example,

\footnotetext{
${ }^{6}$ John Gerring, "What Is a Case Study and What Is It Good for?" American Political Science Review 98, no. 2 (May 2004): 341-54; John Gerring, "Causation: A Unified Framework for the Social Sciences," Journal of Theoretical Politics 17, no. 2 (2005): 163-98; Kosuke Imai, Luke Keele, Dustin Tingley, and Teppei Yamamoto, "Unpacking the Black Box of Causality: Learning about Causal Mechanisms from Experimental and Observational Studies," American Political Science Review 105, no. 5 (November 2011): 765-89.

${ }^{7}$ As critics of audience cost theory can rightly point out, the difficulty in assessing the theory stands as prima facie evidence against the theory. That academic audiences have failed to be sufficiently critical of audience cost theory, however, is not an argument for why readers should be more credulous about flawed criticisms.

${ }^{8}$ Joe Eyerman and Robert A. Hart, Jr., "An Empirical Test of the Audience Cost Proposition: Democracy Speaks Louder than Words," Journal of Conflict Resolution 40, no. 4 (December 1996): 597-616.

${ }^{9}$ Peter J. Partell and Glenn Palmer, "Audience Costs and Interstate Crises: An Empirical Assessment of Fearon's Model of Dispute Outcomes," International Studies Quarterly 43, no. 2 (June 1999): 389-405.

${ }^{10}$ Christopher Gelpi and Michael Griesdorf, "Winners or Losers? Democracies in International Crisis, 1918-94," American Political Science Review 95, no. 3 (September 2001): 633-47.

${ }^{11}$ Kenneth A. Schultz, Democracy and Coercive Diplomacy (New York: Cambridge University Press, 2001).
} 
that democracies are more likely to exhibit certain advantages during crises, we generally cannot infer causality from this relationship, largely because states realize different types of regimes through decidedly nonrandom processes. Whatever causes democracy may itself be partly or wholly responsible for various desirable democratic attributes. Second, the data sets generally used to test audience cost theory may not be well suited to the task because they include many cases in which leaders make no threats. ${ }^{12}$ Third, this literature is primarily concerned with testing an implication of Fearon's model, that is, that democracies fare better in certain crisis situations. ${ }^{13}$ Yet this implication largely rests on Fearon's assumption that democracies have "stronger domestic audiences." "If If this assumption is incorrect, then there is reason to doubt the specific processes posed in Fearon's model, though we need not abandon the much more general audience costs mechanism. Evidence for or against a democratic advantage can be interpreted as direct support for or against this implication of Fearon's argument, but it is not definitive with respect to the broader causal mechanism. Audience costs may matter, even if Fearon's particular formulation is incorrect, if autocrats are also able to create and use audience costs for foreign policies. $^{15}$

These problems can be overcome through careful use of data and methods, ${ }^{16}$ and by specifying hypotheses that directly test unique implications of theoretical models. ${ }^{17}$ A fourth problem is especially difficult: many statistical methods are not designed to test causal

\footnotetext{
${ }^{12}$ Alexander Downes and Todd Sechser, "The Illusion of Democratic Credibility," International Organization (forthcoming).

${ }^{13}$ Kenneth A. Schultz, “Looking for Audience Costs,” Journal of Conflict Resolution 45, no. 1 (February 2001): 3260.

${ }^{14}$ Fearon, "Domestic Political Audiences," 578.

15 Jessica L. Weeks, “Autocratic Audience Costs: Regime Type and Signaling Resolve,” International Organization 62, no. 1 (Winter 2008): 35-64.

${ }^{16}$ See, for example, Downes and Sechser, "The Illusion of Democratic Credibility."

${ }^{17}$ See, for example, Schultz, "Looking for Audience Costs."
} 
mechanisms, including sophisticated tools designed for causal inference. ${ }^{18}$ These methods may establish that democracies can make more credible threats, but even so, we would not know whether this occurs through the creation of audience costs. ${ }^{19}$ Interaction terms can be used to assess whether two processes jointly contribute to a given effect. If the interaction $\mathrm{X}_{1} * \mathrm{X}_{2}$ has a significant relationship with $\mathrm{Y}$, we may infer that the effect of $\mathrm{X}_{1}$ on $\mathrm{Y}$ significantly increases or decreases with $\mathrm{X}_{2}$, suggesting that $\mathrm{X}_{2}$ is involved in the mechanism by which $\mathrm{X}_{1}$ affects $\mathrm{Y}$. Such a design is useful for addressing this problem, but recent work suggests that it must be used with care: the extent to which interaction terms allow, such inference is frequently misunderstood, requires additional assumptions, and "provides only indirect evidence about a hypothesized causal mechanism." 20

The difficulty of testing causal mechanisms using quantitative methods is a key motivator behind recent attempts to test audience cost theory with historical case studies. ${ }^{21}$ Both Trachtenberg and Snyder and Borghard use forms of process tracing, in each case finding little evidence of the audience costs mechanism at work. Although advocates of these methods argue with some justification that process tracing is better suited for testing causal mechanisms, neither study makes a convincing effort to explain why the approach is appropriate in the context of audience costs. $^{22}$ We acknowledge that carefully crafted case studies can help identify causal mechanisms in many instances, but we are skeptical about the extent to which process tracing can be used to uncover the audience costs mechanism.

\footnotetext{
${ }^{18}$ Consider the "gold standard" for quantitative causal inference: the randomized drug trial. Such a research design is well suited to determining whether treatment with a particular drug causes a change in patients' symptoms. It cannot determine, however, how the drug caused that effect.

${ }^{19}$ For a similar argument, see Snyder and Borghard, "The Cost of Empty Threats."

${ }^{20}$ Imai et al., "Unpacking the Black Box of Causality," 785.

${ }^{21}$ Trachtenberg, "Audience Costs: An Historical Analysis"; Snyder and Borghard, "The Cost of Empty Threats."

${ }^{22}$ See generally Alexander L. George and Andrew Bennett, Case Studies and Theory Development in the Social Sciences (Cambridge, MA: MIT Press, 2005).
} 
Audience costs are difficult to observe directly. Trachtenberg notes that quantitative tests are limited because "statistical inference deals with observables." ${ }^{23}$ Yet case studies must also focus on observables. One might argue that case studies are useful for taking into account more observables than quantitative research (especially when observables are difficult to quantify), but case studies fare no better when taking into account unobservables. It is not clear how researchers should process trace nonevents, for example. Factors that are not readily observable include actors' intentions, the extent to which actors are able to transmit information to others, and how observers perceive information.

Conclusions regarding whether the audience costs mechanism was employed often turn on analyses of leaders' intentions when making key public pronouncements, such as those made by Lord Salisbury's during the Fashoda crisis, Lloyd George during the Agadir crisis, and Kennedy during the Cuban Missile Crisis. Yet these intentions are particularly difficult to distill. Primary sources can provide insight into leaders' intentions, but concluding that a leader did not use a public address to create audience costs because there is not enough documentary evidence that he did so requires one to make untenable assumptions about both the documentation and leaders' incentives. That a leader would clearly document his or her plans to use a public pronouncement to create audience costs is unlikely; a public that learned of a leader's intentions would be less likely to play the role required of it by the theory. ${ }^{24}$ It might be said that the first rule of audience costs is that you do not talk about audience costs. Leaders may, at times, document such intentions privately, assuming they will not become public for many decades. On the other hand, they may not, given limited time, interest, or introspection. To reject a theory based on the lack of such documentation requires us to assume a leader would generally record

\footnotetext{
${ }^{23}$ Trachtenberg, "Audience Costs: An Historical Analysis," 3.

${ }^{24}$ Neither Trachtenberg nor Snyder and Borghard examine cases where audience costs are discussed but rejected as an option.
} 
his intentions, a problematic assumption that may bias results and bears further attention. That one can assume leaders are generally conscious of their own motives is also not clear. The theory requires only that leaders instinctively identify a connection between their words, deeds, and the repercussions of public perceptions, not that leaders intellectualize or enunciate this connection for others. If politicians lack introspection, or are short on candor, then we may err in assuming their confidences, or private musings, are accurate records of motive or design. ${ }^{25}$

Concerns about case selection also leave us unconvinced of the extent to which the research designs used by these studies are suitable. Trachtenberg and Snyder and Borghard use versions of a "most likely" case design. ${ }^{26}$ Although both projects claim to be looking for evidence of a causal mechanism, each uses a research design intended to test hypotheses regarding causal effects. The most likely design is intended to test whether $\mathrm{X}$ affects $\mathrm{Y}$, rather than how $\mathrm{X}$ affects $\mathrm{Y}$. Both papers aim to identify the cases in which one is most likely to observe leaders creating audience costs in order to send credible signals to other leaders. The logic of inference here is that a lack of support for the theory, even in those cases in which it is most likely to operate, provides strong evidence against the theory.

Both projects thus fail to test directly the key implication of Fearon's theory. The dependent variable in each case is the extent to which audience costs matter in crises, and the implicit hypothesis is that the costs should play critical roles in crises that meet certain scope conditions. Both articles present evidence against this hypothesis. To the extent that we might accept the evidence on its own terms, following the logic of a most likely design we could infer

\footnotetext{
${ }^{25}$ Although Gerring argues convincingly that case studies can be useful when we are more interested in learning about a causal mechanism than a causal effect, he does not offer solutions to the issues specific to testing audience cost theory that we have raised. Gerring, "Causation."

${ }^{26}$ Harry Eckstein, "Case Studies in Political Science," in Handbook of Political Science, Vol. 1, Political Science: Scope and Theory, ed. Fred Greenstein and Nelson W. Polsby (Reading, MA: Addison-Wesley, 1975), 79-138. Unfortunately, both sets of authors are explicit about their case selection process, but neither is explicit regarding their research design.
} 
audience costs are no more likely to play a role in the types of crises the authors examine than in other crises. Evidence provided by Trachtenberg and Snyder and Borghard thus weighs against audience cost theory, but does not result from direct tests of Fearon's argument, for two reasons. First, Fearon's hypothesis is that democracies less often back down in crises and are better able to generate audience costs. Neither Trachtenberg nor Snyder and Borghard test this hypothesis, focusing instead on whether audience costs are more likely to be used in certain types of crises. Second, Fearon argues that the creation of audience costs is a mechanism that allows leaders to send more credible signals during a crisis. Neither Trachtenberg nor Snyder and Borghard provide evidence that would lead us to believe leaders cannot use audience costs in this way.

\section{$\leq$ A $>$ THE MICRO-FOUNDATIONS OF AUDIENCE COSTS $\leq / \mathrm{A}>$}

Causal mechanisms are difficult to test. This seems to be especially true with audience costs, in part because actors have strategic incentives to hide or misinterpret their intentions. Although the analysis of crisis behavior — through case studies or statistical analysis - can be used to shed light on the debate, finding conclusive evidence for or against audience cost theory may prove elusive. As with other formal models, the theory could be tested by careful specification of comparative statics combined with empirical work. We also encourage scholars to focus on testing the theory where it is arguably weakest: in its micro-foundations. Within the limited space here, we identify a foundation that deserves particular attention: the availability of information to the domestic public.

The theory assumes the public has sufficient information regarding crisis behavior, including, crucially, information that can be manipulated by leaders seeking to create audience costs. This is a very strong assumption and one that is empirically uncertain. Indeed, if we are to observe the audience costs mechanism in action, we are most likely to do so through the process 
of leaders communicating with their publics. The key issue here can be summed up in the following question: Do publics have sufficient information regarding crisis behavior, even when leaders seek to signal to other states by creating audience costs?

There are several reasons to think domestic audiences may not be as well informed as the theory requires. First, the public is not generally knowledgeable about politics, especially about foreign policy. ${ }^{27}$ The public may overcome this problem by using "information shortcuts," but how or whether leaders can create audience costs in light of these shortcuts is not clear. ${ }^{28}$ Second, understandings of political communication have been questioned by recent advances in cognitive science. It may no longer be safe to pretend publics can process signals in the ways assumed by audience cost theory. Finally, if we assume the media are effective and unbiased conduits of information, then we might readily observe audience costs in the making in media content. Such an assumption is theoretically and empirically tenuous, however, given that the role of the media in this process is unclear. ${ }^{29}$ If the media fail to convey information to publics, then the ability of leaders to use the audience costs mechanism will be limited. ${ }^{30}$ Just as importantly, if the media are ineffective in the role of mobilizing public attention to leader commitments, then looking for audience costs by analyzing media reports will lead to biased conclusions about whether leaders actually use audience costs.

\footnotetext{
${ }^{27}$ John Zaller, The Nature and Origins of Mass Opinion (New York: Cambridge University Press, 1992); Ole R. Holsti, Public Opinion and American Foreign Policy (Ann Arbor: University of Michigan Press, 2004).

${ }^{28}$ On "information shortcuts," see Samuel L. Popkin, The Reasoning Voter: Communication and Persuasion in Presidential Campaigns (Chicago: University of Chicago Press, 1994).

${ }^{29}$ Branislav L. Slantchev, "Politicians, the Media, and Domestic Audience Costs," International Studies Quarterly 50, no. 2 (June 2006): 445-77; Matthew A. Baum and Philip B.K. Potter, "The Relationships Between Mass Media, Public Opinion, and Foreign Policy: Toward a Theoretical Synthesis," Annual Review of Political Science 11 (2008): 39-65.

${ }^{30}$ Slantchev, "Politicians, the Media, and Domestic Audience Costs."
} 
We echo Potter and Baum in encouraging scholars to continue to refine the links between the crisis bargaining literature and the political communications literature. ${ }^{31}$ We hope by doing so scholars will be better equipped to understand the information system in crisis bargaining, an understanding that is crucial in determining whether and how audience costs mechanisms work. Experiments will be particularly useful in evaluating information transmission, an approach that has been pursued by several scholars. ${ }^{32}$ Although experiments face questions of external validity, this type of micro-level evidence can serve as an important complement to work studying crisis behavior directly.

\footnotetext{
${ }^{31}$ Philip B.K. Potter and Matthew A. Baum, "Democratic Peace, Democratic Audience Costs, and Political Communication," Political Communication 27 (2010): 453-70.

${ }^{32}$ Michael Tomz, "Domestic Audience Costs in International Relations: An Experimental Approach," International Organization 61, no. 4 (Fall 2007): 821-40; Matthew S. Levendusky and Michael C. Horowitz, "When Backing Down is the Right Decision," Journal of Politics (forthcoming).
} 